\title{
MICROMORPHOLOGY OF FLOWERS, ANATOMY AND ULTRASTRUCTURE OF Chamomilla recutita (L.) Rausch. (ASTERACEAE) NECTARY
}

\author{
Aneta Sulborska \\ Department of Botany, University of Life Science in Lublin, ul. Akademicka 15, 20-950 Lublin, Poland \\ e-mail: aneta.sulborska@up.lublin.pl
}

Received: 10.09.2011

\section{Abstract}

Investigations of the micromorphology of flowers and the structure of nectaries in Chamomilla recutita L. (Rausch.) were carried out with the use of stereoscopic, light, scanning and transmission electron microscopy. Biseriate glandular trichomes consisting of 5-6 cell layers were found on the surface of the corollas of ray and disc florets. Accumulation of secretion within the subcuticular space was accompanied by degradation of trichome cells. Secretion release followed rupture of the cuticle in the apical part of the trichome. The ovary of the ray florets exhibited characteristic ribs covered with epidermis composed of radially elongated palisade cells.

Nectariferous glands were present only in the disc florets. The ring-like nectary $(93 \times 163 \mu \mathrm{m}$; height $\mathrm{x}$ diameter $)$ was located above the inferior ovary. The gland structure was formed by single-layer epidermis and 5-8 layers of specialised nectariferous parenchyma. Nectar was released via modified 15-20 $\mu \mathrm{m}$ wide stomata. The guard cells were slightly elevated above the surface of the other epidermal cells or were located slightly below them. The stomatal cells were characterised by small external and internal cuticular ledges. No vascular bundles were observed in the nectary. The gland was supplied by branches of vascular bundles reaching the style and ending at the nectary base. The nectariferous tissue was formed by isodiametric cells with a diameter of 11-20 $\mu \mathrm{m}$. The cell interior was filled with electron dense cytoplasm containing a large nucleus, numerous pleomorphic plastids, mitochondria with a distinct system of cristae, Golgi bodies, ER profiles, and ribosomes. The plastid stroma was characterised by presence of pastoglobuli, intraplastid tubules, and lighter zones. Several small vacuoles were found in each cell. Plasmodesmata were visible in the walls of some cells. Lighter periplasmic space in which apoplastic transport of nectar might take place was observed between the plasmalemma and the cell wall. The presence of an osmiophilic substance in the intercellular spaces additionally corroborates this assumption.

Key words: Chamomilla recutita, flowers, glandular trichomes, nectary, epidermis, nectariferous parenchyma, ultrastructure.

\section{INTRODUCTION}

Chamomilla recutita (Asteraceae) is a wild species growing throughout Europe; in Poland, it is a segetal and ruderal weed (S z w e y k o w s c y , 2003). It is one of the oldest medicinal plants known in ancient Egypt, Greece, and Rome (R u m i ń s k a, 1973).

Due to their structure and location of nectaries, the flowers of Asteraceae representatives have been classified as flowers with completely hidden nectaries (S zafer and Wojtusiakowa, 1969). Lipiń$\mathrm{s} \mathrm{k} \mathrm{i} \mathrm{(2010)} \mathrm{classified} \mathrm{them} \mathrm{as} \mathrm{hemitropous} \mathrm{flowers,} \mathrm{in}$ which nectaries are located not deep and are accessible to insects with a mouth apparatus of medium-length.

According to Fahn (1952, 1988 a, b, 2000), nectaries in Asteraceae represent the type of the style (stylopodium) that is located at the style base. Such location of the nectariferous tissue in this family has also been found by Kuliev (1959), Es a u (1973), Sulborska and Weryszko-Chmielewska (2006, 2007), Wist and Davis (2006) and Lipiński (2010). S mets (1986) refers to nectaries in Asteraceae as nectaria persistentia associated with persistent flower parts, while Schmid (1988) and Bernarde11o (2007) classify them as gynoecial nectaries.

A majority of species from the family Asteraceae investigated have nectaries only in the disc florets (S a m mataro et al. 1985; S u lborska and Weryszko-Chmielewska, 2006, 2007; Wist and Davis, 2006). In Heterothalamus alienus, however, the nectariferous glands were also present in the ray florets (V o g e 1, 1998).

The data obtained by Fre i (1955) indicate that the nectaries in Asteraceae are uniform in terms of location and shape; Li piński (2010) claims that the nectariferous gland in this family always has the same 
structure. In turn, G u ly á s and P e s t i (1966) reported that ring-shaped, funnel-shaped and cone-shaped glands were observed in the genus Centaurea. In Helianthus annuus flowers, a collar-like discoid nectary was found, which in cross section exhibited a round shape or in the form of a 4- to 8-sided polygonal ring (S a m m a t a ro et al. 1985). In Inula helenium, the nectariferous gland had a shape of a five-armed star with rounded tips ( $\mathrm{S}$ ulborska and Weryszko$\mathrm{Ch}$ m i e le w s k a, 2007), while the nectaries in Achillea millefolium ( $\mathrm{S} \mathrm{ulborska}$ and $\mathrm{Weryszko-}$ Chmielewska, 2006) and Echinacea purpurea, observed from above, were pentagonal (W ist and D a v i s, 2006).

The secreted nectar is accumulated in the narrow corolla tube, and thus elevated by a few millimetres and accessible to insects (L i p i ńs k i, 2010). In the pistillate phase in the disc florets of Echinacea purpurea, the basal part of the corolla, which functions as a nectar reservoir, was substantially enlarged (W is t and $\mathrm{D}$ a $\mathrm{v}$ is , 2006).

The aim of the present study was to investigate some aspects of flower micromorphology and morphological, anatomical, and ultrastructural features of the nectariferous tissue in Chamomilla recutita, as literature does not provide such data.

\section{MATERIAL AND METHODS}

The Chamomilla recutita L. (Rausch.) flowers studied (in the full bloom phase) originated from the collection of medicinal plants in the UMCS Botanical Garden in Lublin. Observations were performed with the use of stereoscopic (SM), light (LM), scanning electron (SEM) and transmission electron (TEM) microscopy.

SM. In order to localize the nectaries, fresh flowers were examined under a stereoscopic microscope coupled with a Nikon Coolpix 4500 digital camera.

LM. For the analysis of morphological and anatomical features of the nectaries, semi-thin sections $(0,5 \mu \mathrm{m}$ thick) were prepared from longitudinal flower fragments and stained with $1 \%$ methylene blue with $1 \%$ azure II in a $1 \%$ water solution of sodium tetraborate. The material was fixed and embedded in synthetic resin following the method used for the transmission electron microscope.

During the microscopic observations, the height of epidermal cells and diameter of glandular cells were measured $(n=30)$, and the number of layers of glandforming cell was determined. The stomatal width and the height of stomatal cells were measured $(n=10)$. The observations were made under the Jenaval Contrast microscope and the images were taken with Eclipse 400, Nikon.
SEM. Disc florets with nectaries prepared from the anthodia were fixed in a $4 \%$ glutaraldehyde solution in $0,1 \mathrm{M}$ phosphate buffer $\mathrm{pH} 7,0$ at the temperature of $4^{\circ} \mathrm{C}$ for 12 hours. Next, the material was washed with the same buffer 4 times for 20 minutes and dehydrated in alcohol series: 30, 50, 70, 90 and 95\%, which was followed by application of absolute alcohol three times. When dehydrated, the samples were transferred to acetone, critical point dried in liquid $\mathrm{CO}_{2}$ using Bal-Tec CPD 030 and coated with gold and platinum using the Polaron SC 7640 sputter coater. The surface of the nectaries was examined and imaged under the BS 301 scanning electron microscope coupled with the Tescan attachment for digital processing of microscope imaging.

TEM. Fragments of disc florets were fixed in $2 \%$ paraformaldehyde and 2,5\% glutaraldehyde in 0,1 $\mathrm{M}$ cacodylane buffer with $\mathrm{pH} 7,4$ at room temperature for 2 hours and next at the temperature of $4^{\circ} \mathrm{C}$ for 12 hours. The samples were then washed with $1 \mathrm{M}$ cacodylane buffer at the temperature of $4^{\circ} \mathrm{C}$ for 24 hours and underwent osmosis in $1 \% \mathrm{OsO}_{4}$; next they were transferred to redistilled water and stained in a $0,5 \%$ water solution of uranyl acetate. In the next step, the material was dehydrated in an alcohol series and by increasing the concentrations of propylene oxide in alcohol, reaching pure propylene oxide. The samples were embedded in Spurr Low Viscosity resin for 12 hours at the temperature of $70^{\circ} \mathrm{C}$. The material thus prepared was sliced into $60 \mathrm{~nm}$-thick sections with a Reichert Ultracut $\mathrm{S}$ microtome. Ultrathin sections were treated with an $8 \%$ solution of uranyl acetate in $0,5 \%$ acetic acid and with lead citrate. The observations and documentation were made with the use of a BS-500 Tesla electron microscope.

\section{RESULTS}

\section{Morphology and anatomy of the flowers}

The pseudanthia of Chamomilla recutita imitating a single flower were composed of marginal ray florets and numerous internal disc florets (Fig. 1A). The corolla of the ray florets was connate and formed a tube at the base and an elongated ligule composed of three fused petals in the apical part (Fig. 1C). The ray florets had a pistil, but they were sterile.

The calyx in the disc florets was strongly reduced and teeth-shaped above the inferior ovary (Fig. 1D). The corolla was composed of five fused petals. In its basal part, the corolla tube (mean length $1.6 \mathrm{~mm}$ ) was narrower, and above $1 / 2$ of the length, it was wider and had five apical lobes (Fig. 1B). The disc florets were bisexual, fertile, and they bloomed gradually from the margin towards the centre of the anthodium 
(Fig. 1A). Stamens matured first and next the pistil, which has a style with a two-lobbed stigma emerged from a tube formed by fused stamen heads (Fig. 1B,F). Adaxial and abaxial elongated epidermal cells (papillae) containing dense cytoplasm that stained intensely with toluidine blue were observed in the apical part of the stigma (Fig. 1F-G).

The epidermis of the disc floret corolla was composed of longitudinally undulating cell walls (Fig. 3B,E). The walls were thickened and covered with a thick layer of cuticle (Fig. 3B). The cell interior was filled with large central vacuoles, and the cytoplasm and the organelles were located peripherally (Fig. 3B). Dividing plastids with a well-formed lamellar system and osmiophilic pastoglobuli in the stroma were observed in some cells (Fig. 3F).

Glandular trichomes were observed on the corolla petals (corolla tube and lobes) of the disc florets and on the corolla tube of the ray florets (Fig. 2 A,D-I). Trichomes of this type were also found in the depressions between the ribs on the disc floret ovaries (Figs 1E,H,I; 2B-C) and on the involuclar bracts of the anthodium. The length of the glandular trichomes varied between 69 and $90 \mu \mathrm{m}$, and their mean width was $26 \mu \mathrm{m}$. The trichomes were composed of two rows of cells arranged in tiers (on average, 5-6 tiers) (Fig. 2CF). The particular cell tiers were composed of basal, stalk and glandular cells forming a head (Fig. 2C-F) and exhibited a diverse internal structure. Trichomes in the pre-secretion stage had strongly vacuolized basal and stalk cells, and head cells filled with dense cytoplasm with a visible nucleus (Fig. 2 C-E). In the consecutive development stages of the trichomes, the cuticle surrounding the apical cells was detached, forming a vesicular container for the liquid secretions emitted by the cellulose walls of the apical cells (Fig. $2 \mathrm{C}, \mathrm{G}-\mathrm{H})$. As the amount of secretion increased, the subcuticular space expanded and finally ruptured in the apical part, releasing its content (Fig. 2I). While the subcuticular space expanded, the trichome cells degenerated starting from the top tiers and finally collapsed (Fig. 2G-H).

The ovary of the disc florets exhibited characteristic organ-parallel ribs (Fig. 1E; 2B), which had numerous, transversely arranged cuticular ledges (Fig. 2B). Observations made under the light microscope revealed palisade epidermis covering the ribs (Fig. 1H-I). Its cells were strongly radially elongated and the external cell wall viewed under the TEM was thickened and undulate (Fig. 3A). Large periplasmic space was visible between the radial walls and cell protoplast (Fig. 3A,C). The plasmalemma formed an undulate line and was detached from the cell wall (Fig. $3 \mathrm{D})$. The peripheral zone of the mesoplasm contained mitochondria, Golgi bodies with detaching vesicles, plastids, osmiophilic structures and numerous ribosomes (Fig. 3A,C,D). An empty space containing dark, fibrillar structures were observed between the walls of some cells (Fig. 3D).

\section{The structure and ultrastructure of the nectary}

Nectaries in the species studied were present only in disc florets (Fig. 1D-E, H-I). They were located at the base of the corolla tube above the inferior ovary. They were ring-shaped and partly surrounded the stylopodium (Fig. 1D, H-I), whose height and diameter were $93 \mu \mathrm{m}$ and $163 \mu \mathrm{m}$, respectively (Table 1 ).

The nectaries were built of single-layered epidermis and 5-8 layers of glandular cells (Table 2). A thin cuticle layer was visible on the surface of regularly arranged epidermal cells (Figs 1J, 4A). They were slightly smaller than the nectariferous parenchyma cells (Table 2). The epidermal cells contained large central vacuoles and strands of electron-dense peripheral cytoplasm, which indicated polarisation of the protoplast elements. Most organelles were located at the basal contiguous wall. The nucleus and most plastids were always located there (Fig. 4A).

The glandular cells of the nectary differed distinctly from the neighbouring parenchymal cells as they were smaller and had denser cytoplasm (Fig. 1HI). Electronograms showed small spaces between the glandular cells, which were smaller at the base of the gland (Fig. 4A-E). The isodiametric parenchymal cells of the nectary were characterised by electron-dense cytoplasm and presence of a large, often lobular nucleus with a distinct dark chromatin skeleton (Fig. 4B-D). The cells had usually pleomorphic plastids containing osmiophilic pastoglobuli, intraplastid tubules and lighter zones (Fig. 4B-F). No starch grains were visible in the plastids. The plastids often formed aggregations by fusing their membranes as if merging with each other (Fig. 4F). Similar fusion was evident between the plastid and vacuole (Fig. 4D). Other abundant organelles were Golgi bodies and mitochondria with a distinct system of cristae (Fig. 4B-E). A large endoplasmic reticulum network surrounded the nuclei and other cell organelles, and was concentrated near the cell wall (Fig. 4C-F).

Numerous tiny vacuoles were present in the cells (Fig. 4B-D). They frequently contained dark, fibrous material and secretion vesicles. Fused vacuoles were similarly common (Fig. 4B-D). Free ribosomes and ribosomes connected with endoplasmic reticulum cisternae were located in the cell cytoplasm. The walls of the viewed cells were characterised by high electron density and were usually thin (Figs 1J, 4A-F). They contained plasmodesmata (Fig. 4E), which implied 
intense substance exchange between neighbouring cells possibly associated with symplastic nectar transport. The plasmalemma was characteristically undulate and was often detached from the wall, thereby forming a lighter periplasmic space. The presence of this space (Fig. 4C,E) between the cell wall and plamalemma may in turn indicate apoplastic transport of nectarifeous substances. Dark secretion was visible in the small intercellular spaces (Fig. 4E).

Nectar was released via modified stomata located in the glandular epidermis (Fig. 1J-L). A small substomatal space was visible below each modified stomata (Fig. 1J-L). The stomatal cells were slightly elevated above the surface of the epidermal cells or they were located slightly below these cells (Fig. 1JL). Large, centrally located cell nuclei were visible in the stomatal cells (Fig. 1J-L). Small external and internal cuticular ledges were observed at the stomatal pore (Fig. 1J-L). A majority of the stomata were open. Comparison of the nectaries in the early and full nectar secretion phases demonstrated an increase in the stomate width (measured including the pore) by $4,1 \mu \mathrm{m}$ (Table 2), which may have been related with enlargement of the pore during nectar secretion. The height of the stomata ranged from 6,5 to $13 \mathrm{~mm}$ in the early secretion phase and was slightly smaller during full secretion (Table 2).

No vascular bundles were found in the chamomile nectaries; only the subglandular tissue exhibited phloem strands - branches of vascular bundles of the pistil style supplying the nectary.

Table 1.

Characteristics of the Chamomilla recutita nectary and corolla of disc florets

\begin{tabular}{lccc}
\hline \multicolumn{1}{c}{ Studied features } & \multicolumn{2}{c}{ Results of measurements } \\
\cline { 2 - 3 } & Range & Mean & SD \\
\hline Length of the floret corolla $(\mathrm{mm})$ & $1.40-1.70$ & 1.60 & \pm 7.13 \\
Height of the nectary $(\mu \mathrm{m})$ & $77.10-110.51$ & 92.71 & \pm 11.65 \\
Outer diameter of the nectary $(\mu \mathrm{m})$ & $151.63-174.77$ & 163.20 & \pm 7.59 \\
\hline
\end{tabular}

Table 2.

Some anatomical features of the floral nectary of $\mathrm{Ch}$. recutita at two developmental stages

\begin{tabular}{|c|c|c|c|c|}
\hline \multirow{2}{*}{ Studied features } & \multirow{2}{*}{$\begin{array}{c}\text { Stage of development of } \\
\text { nectary }\end{array}$} & \multicolumn{3}{|c|}{ Results of measurements } \\
\hline & & Range & Mean & SD \\
\hline \multirow{2}{*}{ Number of the gland cell layers } & Early secretion & $6.0-8.0$ & 7.0 & \pm 0.71 \\
\hline & Full secretion & $5.0-7.0$ & 6,0 & \pm 0.71 \\
\hline \multirow{2}{*}{$\begin{array}{l}\text { Height of the epidermal cells } \\
(\mu \mathrm{m})\end{array}$} & Early secretion & $14.67-20.37$ & 17.31 & \pm 1.63 \\
\hline & Full secretion & $8.15-17.93$ & 13,91 & \pm 2.06 \\
\hline \multirow{2}{*}{$\begin{array}{l}\text { Major diameter of the gland } \\
\text { cells }(\mu \mathrm{m})\end{array}$} & Early secretion & $11.41-26.08$ & 18.57 & \pm 3.09 \\
\hline & Full secretion & $9.78-19.56$ & 16.60 & \pm 2.59 \\
\hline \multirow{2}{*}{ Width of stomata $(\mu \mathrm{m})$} & Early secretion & $6.52-19.56$ & 15.48 & \pm 5.33 \\
\hline & Full secretion & $17.93-22.82$ & 19.56 & \pm 1.72 \\
\hline \multirow{2}{*}{$\begin{array}{l}\text { Height of the stomatal cells } \\
(\mu \mathrm{m})\end{array}$} & Early secretion & $6.52-13.04$ & 8.48 & \pm 1.68 \\
\hline & Full secretion & $6.52-11.41$ & 7.96 & \pm 1.06 \\
\hline
\end{tabular}



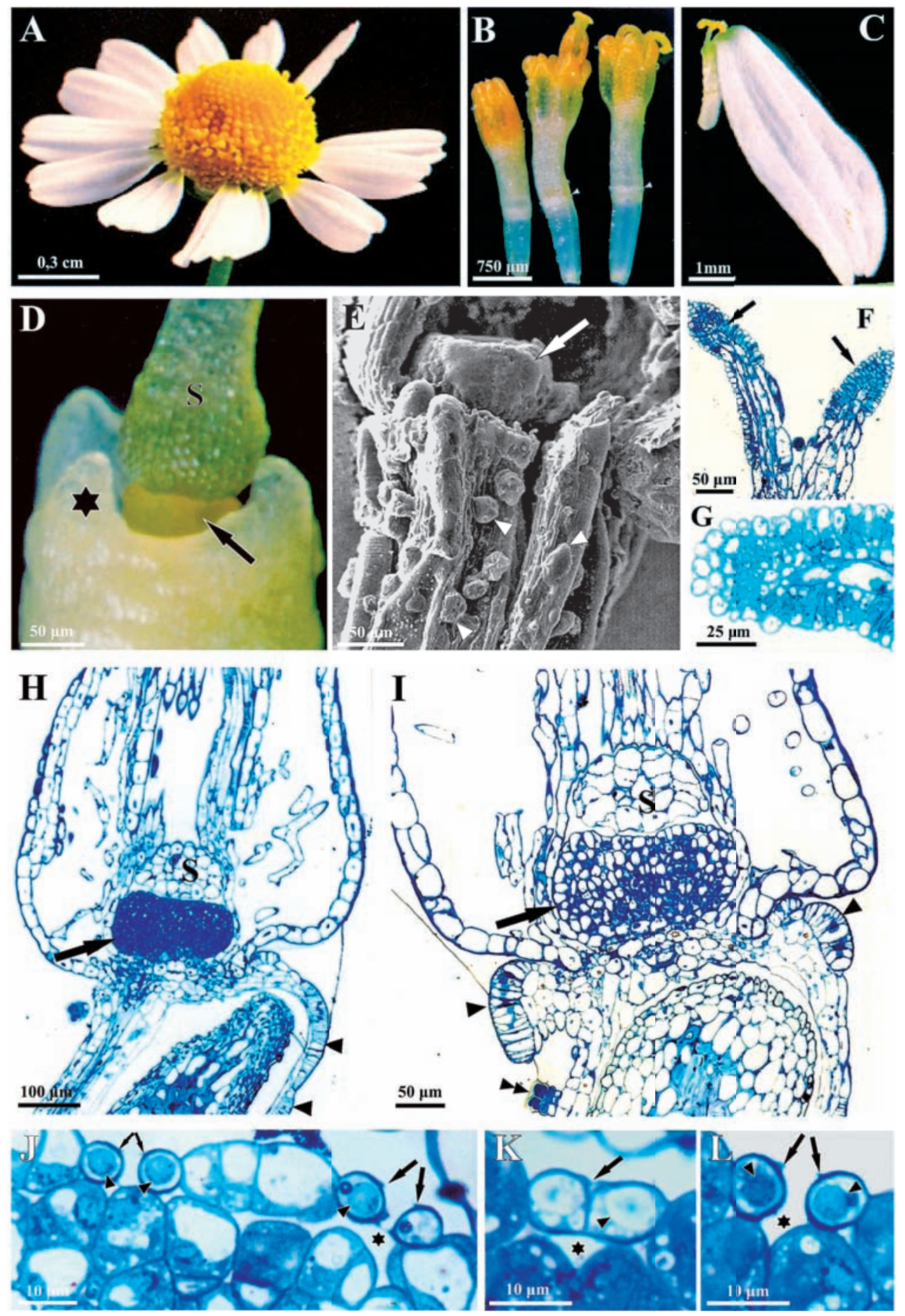

Fig. 1.

A - Anthodium of Chamomilla recutita.

B - Disc florets in different stages of anthesis.

C - Ray floret.

D - Portion of disc floret without corolla and with a fragment of the pistil style (S). The arrow indicates the nectary, asterisk reduced calyx.

E - Portion of the disc floret (SEM) with a visible nectary (arrow) and glandular trichomes on the ovary (arrowheads).

$\mathrm{F}$ - Part of stigma in the disc floret with papillae in the apical part (arrows).

$\mathrm{G}$ - Papillae in the apical part of the stigma in the disc floret.

H-I - Portions of longitudinal sections of disc florets with a visible nectary (arrows) in phase of early secretion (H) and in full secretion (I). Arrowheads indicate palisade epidermal cells forming ribs on the ovary; double arrowhead - glandular trichome. $\mathrm{S}-$ pistil style.

J-L - Stomata on the surface of the nectary. Arrows indicate cuticular ledges, arrowheads - nuclei, asterisks -substomatal space. 

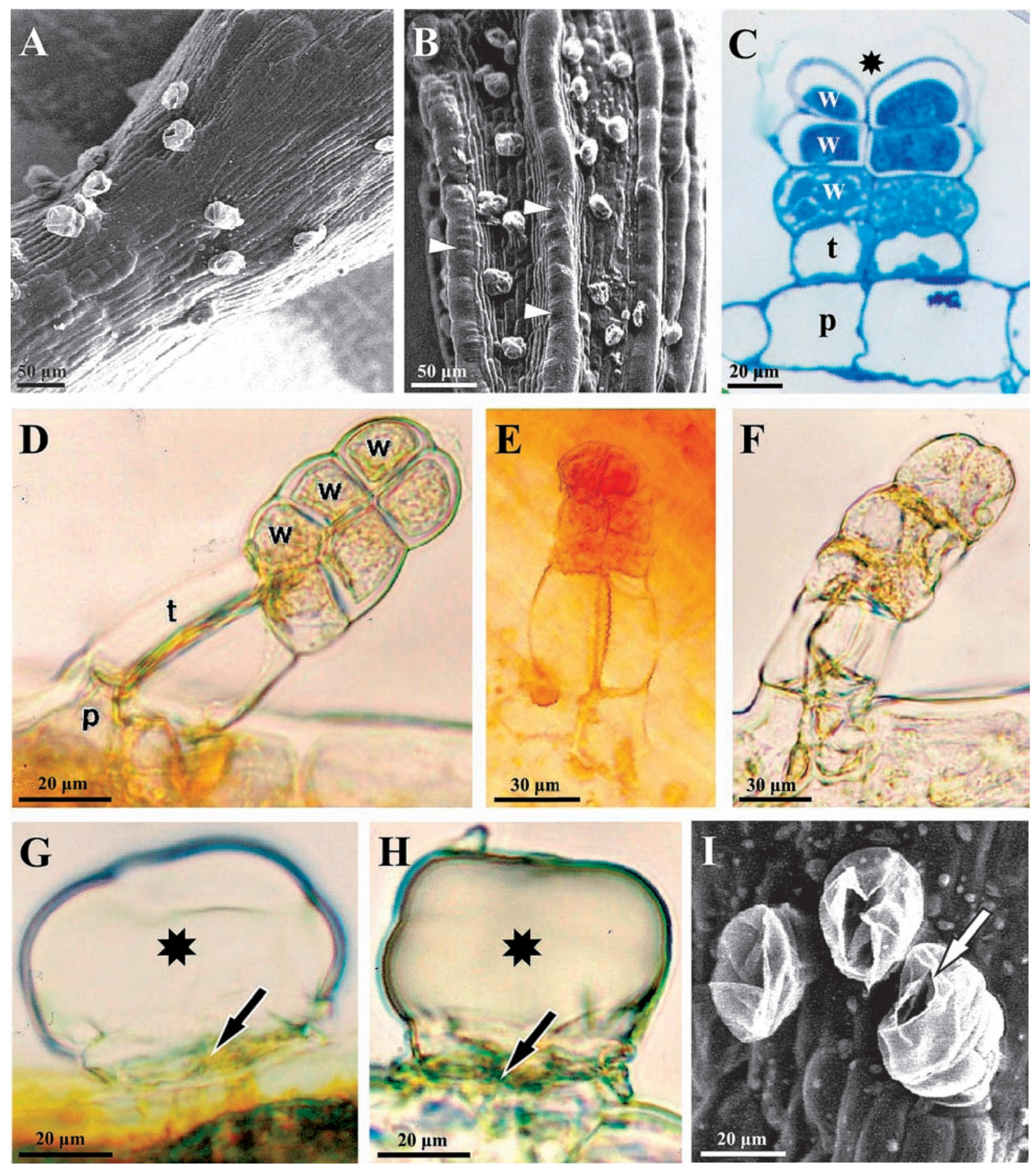

Fig. 2.

A - Portion of corolla of the disc floret with glandular trichomes.

B - Glandular trichomes on the ovary of the disc floret. On the ribs - visible transverse cuticle ledges (arrowheads).

$\mathrm{C}$ - Biseriate glandular trichome on the ovary of the disc floret; $\mathrm{p}$ - basal cells, $\mathrm{t}$ - stalk cells, $\mathrm{w}$ - glandular cells, asterisk subcuticular space.

D-E - Glandular trichomes on the surface of the disc floret. D - a visible pair of basal cells (p), pair of stalk cells ( $(t)$ and three pairs of glandular cells (w) with dense cytoplasm forming the head.

F - A glandular hair from the corolla tube of the ray floret.

G-H - Glandular trichomes on the surface of epidermis of the disc floret corolla. Visible collapsed hair cells (arrows) and big subcuticular space filled with secretion (asterisk).

I - Glandular trichomes (SEM) on the surface of the corolla tube of the disc floret. Arrow indicate ruptured cuticle at the top. 

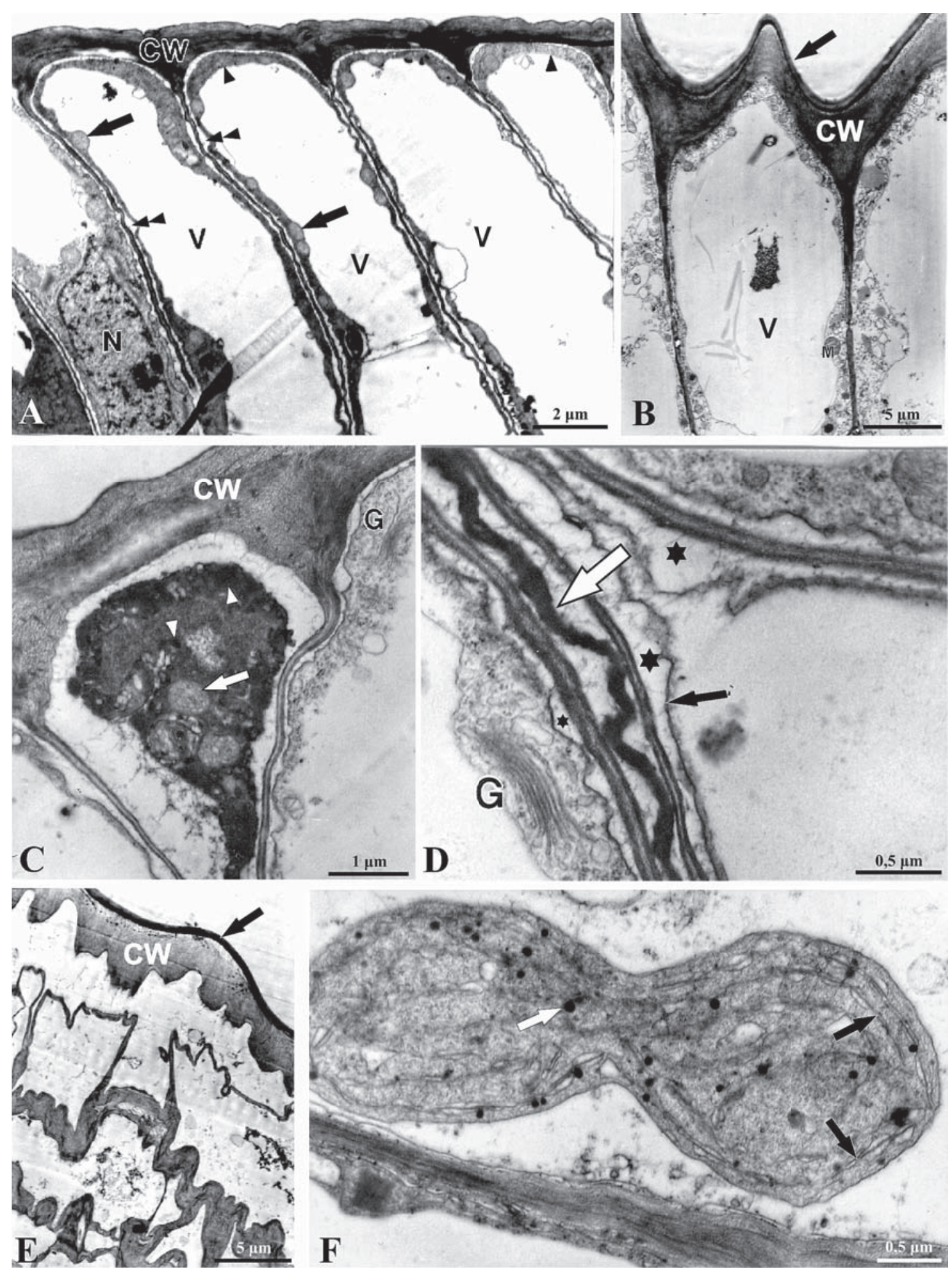

Fig. 3.

A - Portions of palisade epidermis cells on the surface of the ovary of the disc floret. Arrows indicate mitochondria, arrow heads - peripheral cytoplasm. Double arrowheads - periplasmic space. $\mathrm{CW}$ - thickened outer cell walls, $\mathrm{V}$ - vacuoles, $\mathrm{N}$ - nucleus.

B, E - Portions of epidermal cells of the corolla petal of the disc floret. V - vacuoles, M - mitochondria, arrow - cuticle.

C-D - Portions of epidermal cells on the ovary of the disc floret. C - arrow indicates plastids, arrow heads - osmiophilic structures. D - visible dark substance between the cell walls (white arrow), detached plasmalemma (black arrow) and periplasmic space (asterisks).

E - Dividing plastid in the epidermal cell of the disc floret. Visible lamelles (black arrows) and osmiophilic globuli (white arrow) in the stroma. 

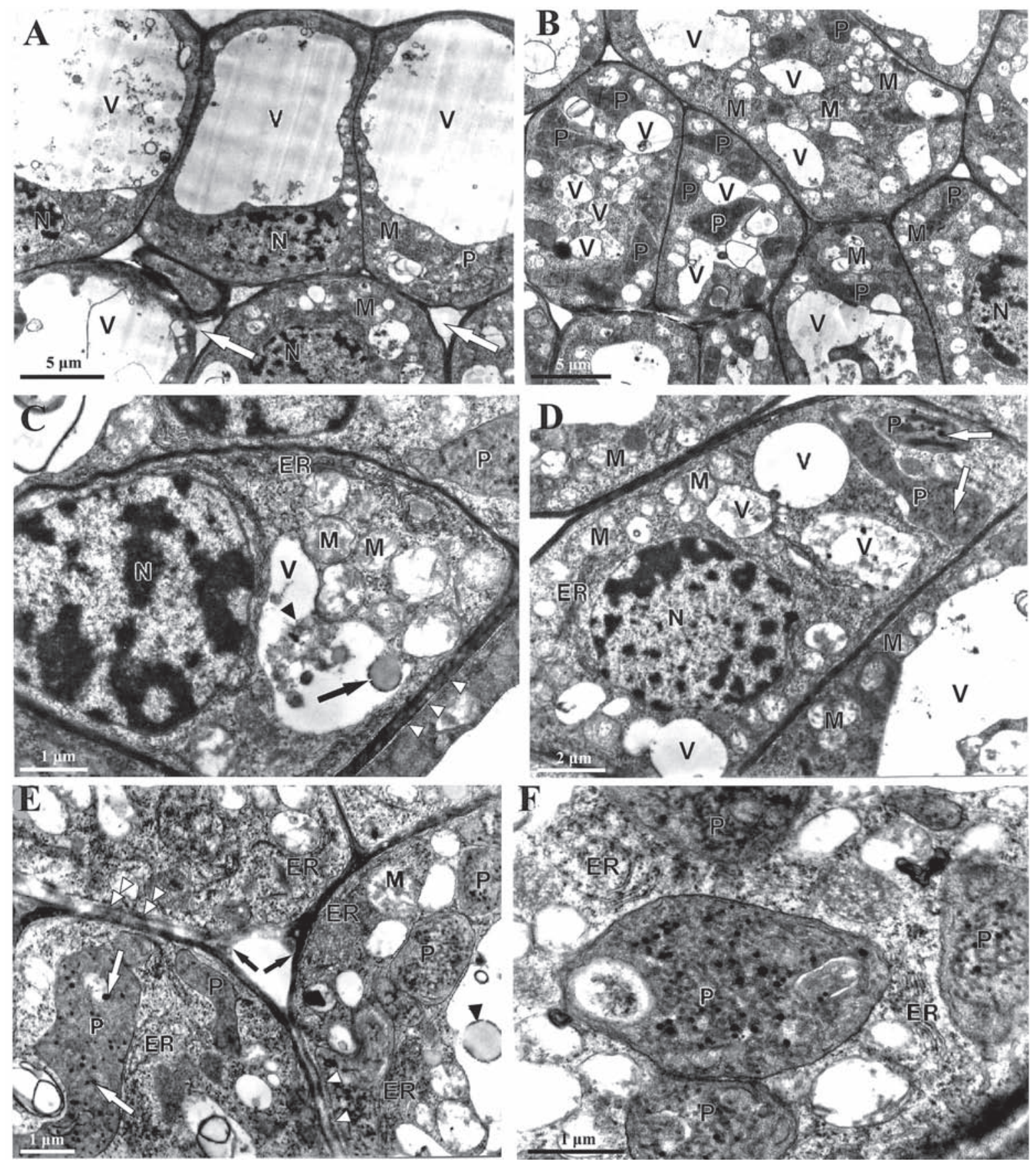

Fig. 4.

A - Epidermal cells of the nectary (TEM). Visible big vacuoles (V), nuclei (N), plastids (P), mitochondria (M) and intercellular spaces (arrows).

B - Young cells (after mitosis) in the glandular layer of the nectary. In the cytoplasm, visible pleomorphic plastids (P), small vacuoles (V), abundant mitochondria (M).

$\mathrm{C}$ - Cell of the subepidermal layer of nectary tissue. Visible big nucleus with dark chromatin (N), plastids (P), mitochondria (M), tubules of endoplasmic reticulum (ER), drops of secretion (arrow) and fibrillar substance (black arrowhead) in the vacuole (V), periplasmic space (white arrowheads).

D - Cell of the third layer of nectariferous parenchyma. Visible nucleus $(\mathrm{N})$, vacuoles $(\mathrm{V})$, plastids $(\mathrm{P})$ with globuli of secretion (arrows), mitochondria (M) and profiles of endoplasmic reticulum (ER).

E - Cells of the fourth and fifth layer of nectariferous parenchyma with visible intercellular space and secretion in the corners (black arrows). Inside cells, there are plastids (P) with osmiophilic globuli (white arrows), mitochondria (M). Numerous profiles of endoplasmic reticulum (ER) and secretion in the vacuole (black arrow head). White arrowheads indicate the periplasmic space, double arrowheads - plasmodesmata.

F - Plastids (P) in the glandular cell of the nectary with visible osmiophilic globuli, tubular structures and light zones. Close to the plastids, there are profiles of endoplasmic reticulum (ER). 


\section{DISCUSSION}

The results of the present study showed that chamomile nectaries were located in the disc florets above the inferior ovary and partly surrounded the stylopodium. Similar location of nectaries in Asteraceae was reported by other authors ( $\mathrm{S}$ a $\mathrm{m} \mathrm{m}$ at a ro et al. 1985; S mets, 1986; S ulborska and Werys zko-Chmielewska, 2006, 2007; Wist and Davies, 2006; Li piński, 2010). Pel'menev (1985) reported that nectariferous tissue in Silphium perfoliatum flowers was located in a shallow depression at the apex of the inferior ovary and the depression itself was lined with glandular tissue, which was not observed in the species in this study.

From above, chamomile nectaries are discoid and rounded. In other Asteraceae, the gland has been reported to be tube-, ring-, funnel- or cone-shaped (Gu l y á s and Pe s t i, 1966; S m e t s, 1986), pentagonal (S a m m a t a ro et al. 1985; S u lbor ska and Weryszko-Chmielewska, 2006; Wist and $\mathrm{D}$ a v i e s, 2006), or to have the shape of a five-armed star with rounded corners ( $\mathrm{Sulborska}$ and $\mathrm{We}$ ryszko-Chmielew ska, 2007).

Nectaries of Chamomilla reached small sizes $(93 \times 163 \mu \mathrm{m}$; height $\mathrm{x}$ diameter), compared with glands in other species from this family: 200-360 $\mu \mathrm{m}$ $\times 470-800 \mu \mathrm{m}$ in Helianthus annuus ( $\mathrm{S}$ a m m a t aro et al. 1985), 122-154 $\mu \mathrm{m} \times 360 \mu \mathrm{m}$ in Echinacea purpurea (W is t and D a vi es, 2006), 129×492 mm in Inula helenium ( $\mathrm{S} \mathrm{u} 1 \mathrm{~b}$ or s k a and W e ry s z k o- Chmielewska, 2007). Even in yarrow, where the size of disc florets is comparable to that in chamomile, the nectaries were bigger $(182 \times 299 \mu \mathrm{m}$; height $\mathrm{x}$ diameter) (Sulborska and Weryszko- Chmielewska, 2006). Fahn (1949), T a uber et al. (1980) and Wery szko-Ch mielew ska et al. (2003) reported that the nectary size was positively correlated with the amount of secreted nectar.

The chamomile nectaries were built of single-layered epidermis and 5-8 tiers of glandular cells. A similar parenchyma was found in the nectaries of Achillea millefolium (6 glandular cell layers on average) (S u lborska and Werys zko-Chmielew $\mathrm{ska}, 2006)$ and Inula helenium (5-9 glandular cell layers) (S u lborska and Weryszko-Chmielew ska, 2007). The shape (in longitudinal section) of the nectariferous parenchyma cells in chamomile was circular or oval along the entire length of the nectary; this was also reported by $\mathrm{Gu} 1 \mathrm{y}$ á s and $\mathrm{Pest} \mathrm{i}$ (1966) in Centaurea nigra and C. cyanus. Kuli e v (1959), in turn, found polygonal, prismatic, and other cell shapes. The diameter of the chamomile nectariferous cells did not exceed $19 \mu \mathrm{m}$, which to some extent corresponds to the data on elecampane $(8-20 \mu \mathrm{m})$
(Sulborska and Weryszko-Chmielew$\mathrm{ska}, 2006)$ and the genus Centaurea $(10-20 \mu \mathrm{m})$ (Gulyás and Pesti, 1966). In yarrow, however, the glandular cells were larger and on average reached $27 \mu \mathrm{m}(\mathrm{Sulborska}$ and Weryszko-Chmielew ska, 2006). The chamomile nectariferous cells were tightly packed at the base of the gland and more loosely in the subepidermal layers. A similar cell arrangement was also found by Gulyás and Pesti (1966) in some Centaurea species. It is probable that nectar is initially accumulated in large intercellular spaces, from which it is transported to the surface of the epidermis. Presence of osmiophilic material in the intercellular spaces in the chamomile nectary implies apoplastic transport of nectar within the gland.

Nectar secretion in Chamomilla was mediated by modified stomata located slightly below or above the other epidermal cells. In other representatives of this family, stomata were usually elevated above the surface of other epidermal tissue cells ( $\mathrm{S}$ a $\mathrm{m}$ m a t a ro et al. 1985; Sulborska and Weryszko- Chmielewska, 2006, 2007; Wist and Davi e s, 2006). As a rule, the stomata in the chamomile nectaries studied were open, which was also reported from representatives of this family by other authors (W is t and Davies , 2006; S u l bor sk a and We ryszko-Chmielewska, 2007). Yarrow was the only species to have closed stomatal pores, which was probably associated with the early developmental stage of florets ( $\mathrm{S} \mathrm{u} \mathrm{lborska}$ and Wery s zko- Chmielew ska, 2006). The width of the stomata examined was $15.4 \mathrm{~mm}$ (early nectar secretion phase) and $19.56 \mathrm{~mm}$ (full nectar secretion); it was considerably smaller than the width of the nectary stomata in Inula helenium $(45-53 \mu \mathrm{m})(\mathrm{S} \mathrm{u} 1 \mathrm{~b}$ or s k a and $\mathrm{We}-$ ryszko-Chmielewska, 2006), representatives of Centaurea (20-40 $\mu \mathrm{m})$ (Gulyás and Pesti, 1966), or Helianthus annuus (24-45 $\mu \mathrm{m})(\mathrm{S}$ a $\mathrm{m} \mathrm{m}$ a t a ro et al. 1985).

As reported by Fre y - W y s s ling and Agthe (1950), the differences in nectary vascularisation affect its structure and amounts of produced nectar. The glands in Asteraceae may be vascularised by the phloem, xylem and phloem strands, or may have no vascular bundles (F r e i, 1955). Chamomilla recutita nectaries have no bundles within the nectariferous tissue, likewise the glands in Achillea millefolium (F r e i , 1955; Sulborska and Weryszko-Chmielewska, 2006) and Inula helenium (S u lborska and Weryszko-Chmielewska, 2007). Nectaries vascularised by phloem were observed in flowers of Helianthus annuus, Carduus sp., Centaurea jacea and Cirsium sp. (Fre i, 1955; S a m m a t a r o et al. 1985), and in Echinacea purpurea (W i s t and Davies, 2006); however, in the glands of 
Centaurea montana, phloem and xylem strands were found (Fre i, 1955).

The plastids in chamomile nectariferous cells were characterised by pleomorphic shapes and presence of osmiophilic pastoglobuli. A similar diversity of forms and content was characteristic for plastids in Echinacea purpurea (W ist and Davies, 2006), and yarrow and elecampane nectaries ( $\mathrm{S} \mathrm{u} \mathrm{l} \mathrm{bors} \mathrm{ka}$ and Weryszko-Chmielewska, 2006; 2007). Tubular structures, sometimes filled with osmiophilic secretion, were found in the plastid stroma in the chamomile nectaries. Multitubular and multilamellar bodies were also visible in the nectaries of yarrow, purple coneflower and elecampane $(\mathrm{Sulborska}$ and Weryszko-Chmielewska, 2006, 2007; $\mathrm{W}$ is t and Davies, 2006). Unlike in the nectaries of Echinacea purpurea (W is t and D a vi e s, 2006) and Inula helenium (S u lborska and Werys zk o- Chmielews ka, 2007), the plastids examined did not contain starch grains. Absence of starch may indicate that, before it is eventually secreted, phloem sap undergoes modification in the glandular cells (S t p i c z y ńska et al. 2003).

Likewise in the yarrow, purple coneflower and elecampane nectaries ( $\mathrm{Sulb}$ orska and Wery s zk o-Chmielewska, 2006, 2007; W is t and Dav i e s, 2006), some walls separating the glandular cells in the chamomile nectaries were observed to contain plasmodesmata, whose presence indicates symplastic transport of nectar (F a h n , 1979, 2000).

The chamomile nectariferous cells had a well-developed network of parallel profiles of rough ER, which, according to F a hn (1979), is a characteristic feature of nectariferous cells. The author reports that ER profiles are involved in the transport of pre-nectar in nectariferous tissue and accumulation of nectar in glandular cells.

Numerous mitochondria with a well-developed system of cristae and Golgi bodies were present in the glandular cells examined by the author. Similar observations were made in other Asteraceae by $\mathrm{S} \mathrm{u} \mathrm{l} \mathrm{b} \mathrm{or} \mathrm{-}$ ska and Weryszko-Chmielewska (2006, 2007), and W is t and D a vies (2006). ER profiles and aggregated secretory material were observed near the mitochondria.

In literature, the elongated cells of the palisade epidermis found on the ovary ribs in the chamomile disc florets have been referred to as scalariform slime cells (K o c zwara, 1959; D e ry ng, 1961; Kar ste $n$ et al. 1962). Slow drying out of the slime may promote absorption of water indispensable for achene germination and protect the ovary and fruit from rapid loss of water (P o d b i e l k o w s k i, 1992).

Glandular trichomes consisting of pairs of cells arranged in tiers were found on the florets and anthodium involucre in the species under study. There were 5-6 layers of trichome cells, which is partially consistent with literature data. The trichomes in this family were most commonly arranged in 5 layers (Ascensăo and Pais, 1982, 1987; Duke and Pau 1, 1993; Cornara et al. 2001; Heinrich et al. 2002). The secretion substance was accumulated in the space between the cuticle and the wall of the trichome apical cells, likewise in many other Asteraceae (A s censăo and Pai s, 1982, 1987; Afolayan and M e y e r, 1995; A s c e n s ă o et al. 2001). As the amount of the secretion in the chamomile glandular trichomes increased, the subcuticular space expanded and it was finally ruptured, thereby facilitating secretion of the accumulated material. This was accompanied by gradual trichome cell degradation. This is consistent with other authors' reports, who additionally observed that plastids were first to be lysed and mitochondria were the only organelles persisting until cell collapse (U phof and Hummel, 1962; Vermeer and Peterson, 1979).

\section{REFERENCES}

Afolayan A.J., Meyer J.J.M., 1995. Morphology and ultrastructure of secreting and nonsecreting foliar trichomes of Helichrysum aureonitens (Asteraceae). Int. J. Plant Sci. 156 (4): 481-487.

A scensăo L., Pais M.S., 1982. Secretory trichomes from Artemisia crithmifolia: some ultrastructural aspects. Bull. Soc. Bot. Fr. 129 (1): 83-87.

A scensăo L., Pa is M.S.S., 1987. Glandular trichomes of Artemisia campestris (ssp. maritima): ontogeny and histochemistry of the secretory product. Bot. Gaz. 148 (2): 221-227.

A scensăo L., Silva J.A.T., Barroso J.G., Figueiredo A.C., Pedro L.G., 2001. Glandular trichomes and essential oils of Helichrysum stoechas. Israel J. Plant Sci. 49: 115-122.

Bernarde11o G., 2007. A systematic survey of floral nectaries. [In:] Nectaries and Nectar, S.W. Nicolson, M. Nepi, E. Pacini, (eds), Springer, Dordrecht.

Cornara L., Bononi M., Tateo F., SerratoValenti G., Mariotti M.G., 2001. Trichomes on vegetative and reproductive organs of Stevia rebaudiana (Asteraceae). Structure and secretory products. Plant Biosyst. 135 (1): 25-37.

Deryng J., 1961. Atlas sproszkowanych roślinnych surowców leczniczych. Państwowy Zakład Wydawnictw Lekarskich, Warszawa (in Polish).

Duke S.O., Paul R.N., 1993. Development and fine structure of the glandular trichomes of Artemisia annua L. Int. J. Plant Sci. 154 (1): 107-118.

Es a u K., 1973. Anatomia roślin. Państwowe Wydawnictwo Rolnicze i Leśne, Warszawa (in Polish).

Fahn A., 1949. Studies in the ecology of nectar secretion. Palest. J. Bot. Jerusalem Series, 4: 207-224. 
Fah n A., 1952. On the structure of floral nectaries. Bot. Gaz. 113: 464-470.

Fah n A., 1979. Ultrastructure of nectaries in relation to nectar secretion. Amer. J. Bot. 66 (8): 97-985.

Fahn A., 1988 a. Secretory tissues in vascular plants. New Phytol. 108: 229-257.

Fahn A., 1988 b. Secretory tissues and factors influencing their development. Phyton, 28 (1): 13-26.

Fahn A., 2000. Structure and function of secretory cells. Adv. Bot. Res. 31: 37-75.

Frei E., 1955. Die Innervierung der floralen Nektarien dikotyler Pflanzenfamilien. Berichte der Schweizerischen botanischen Gesellschaft, 65: 98-115 (in German).

Frey-Wyssling A., Agthe C., 1950. Nektar ist ausgeschiedener Phloemsaft. Verhandlungen der schweizerischen naturforschenden Gesellschaft 130: 175-176 (in German).

Gulyás S., Pesti J., 1966. Angaben zur Anatomie der Nektarien der Centaurea. Acta Biol. Szeged. (1-2): 1724 (in German).

Heinrich G., Pfeifhofer H. W., Stabentheiner E., S aw id is T., 2002. Glandular hairs Sigesbeckia jorullensis Kunth (Asteraceae): morphology, histochemistry and composition of essential oil. Ann. Bot. 89: 459-469.

Karsen G., Weber U., Stahl E., 1962. Lehrbuch der Pharmakognosie für Hochschulen. Veb Gustav Fischer Verlag, Jena, (in German)

Koczwara M ., 1959. T. II. Farmakognozja ogólna i szczegółowa. AM w Krakowie, Kraków (in Polish).

Kuliev A.M., 1959. Morfologičeskă evolûciă nektarnikov u pokrytosiemănnyh rastjenij. Kirovabad (in Russian).

Li pińs k i M ., 2010. Pożytki pszczele. Zapylanie i miododajność roślin. Państwowe Wywadnictwo Rolnicze i Leśne, Warszawa, Wyd. Sądecki Bartnik, Stróże (in Polish).

Pel'menev V.K., 1985. Medonosnye rasteniă. Rossel’hozizdat, Moskva (in Russian).

Podbielkowski Z., 1992. Rośliny użytkowe. Wydawnictwo Szkolne i Pedagogiczne, Warszawa (in Polish).

Rumińska A., 1973. Rośliny lecznicze. Państwowe Wydawnictwo Naukowe, Warszawa (in Polish).

Sammataro D., Erickson E.H., Garment M.B., 1985., Ultrastructure of the sunflower nectary. J. Ap. Res. 24 (3): 150-160.

S ch mid R., 1988. Reproductive versus extra - reproductive nectaries - historical perspective and terminological recommendations. Bot. Rev. 54: 179-232.

S mets E., 1986. Localization and systematic importance of the floral nectaries in the Magnoliatae (Dicotyledons). Bull. Jard. Bot. Nat. Belg. 56: 51-76.

Stpiczyńska M., Davies K.L., Gregg A., 2003. Nectary structure and nectar secretion in Maxillaria cocinea (Jacq.) L. O. Williams ex Hodge (Orchidaceae). Ann. Bot. 93: 87-95.

Sulborska A., Weryszko-Chmielewska E., 2006. Morphology, anatomy and ultrastructure of yarrow
(Achillea millefolium L.) floral nectaries. Acta Agrobot. 59 (1): 17-28.

Sulborska A., Weryszko-Chmielewska E., 2007. Anatomy and ultrastructure of floral nectary of Inula helenium L. (Asteraceae). Acta Soc. Bot. Pol. 76 (3): 201-207.

Szafer W., Wojtusiakowa H., 1969. Kwiaty i zwierzęta. Zarys ekologii kwiatów. Państwowe Wydawnictwo Naukowe, Warszawa (in Polish).

Szweykowska A., Szweykowski J., 2003. Słownik botaniczny. Państwowe Wydawnictwo Wiedza Powszechna, Warszawa (in Polish).

Teuber L.R., Albertsen M.C., Barnes D.K., Heichel G.H., 1980. Structure of floral nectaries of alfalfa (Medicago sativa $\mathrm{L}$.) in relation to nectar production. Amer. J. Bot. 67 (4):433-439.

Uphof J.C.T., Hummel K., 1962. Plant hairs. Handbuch der Pflanzenanatomie. Bd. IV, Tl. 5. Gebrüder Borntraeger, Berlin (in German).

Vermeer J., Peters on R.L., 1979. Glandular trichomes on the inflorescence of Chrysanthemum morifolium cv. Dramatic (Compositae). II. Ultrastructure and histochemistry. Can. J. Bot. 57: 714:729.

Vogel S., 1998. Remarcable nectaries: structure, ecology, organophyletic perspectives. IV. Miscellaneous cases. Flora, 193: 225-248.

Weryszko-Chmielewska E., Masierowska M., Konarska A., 2003. Characteristisc of floral nectaries and nectar in two species of Crataegus (Rosaceae). Plant Syst. Evol. 238: 33-41.

Wist T.J., Davis A.R., 2006. Floral nectar production and nectary anatomy and ultrastructue of Echinacea purpurea (Asteraceae). Ann. Bot. 97: 177-193.

\section{Mikromorfologia kwiatów, anatomia i ultrastruktura nektarników Chamomilla recutita (L.) (Asteraceae)}

\section{Streszczenie}

Przy zastosowaniu mikroskopii stereoskopowej, świetlnej, skaningowej i transmisyjnej elektronowej przeprowadzono badania mikromorfologii kwiatów i struktury nektarników Chamomilla recutita L. (Rausch.). Na powierzchni korony kwiatów rurkowatych i języczkowatych stwierdzono obecność dwurzędowych włosków gruczołowych utworzonych z 5-6 pięter komórek. Wraz z gromadzeniem się wydzieliny w przestrzeni subkutykularnej postępowała degradacja komórek włosków. Uwolnienie wydzieliny następowało po rozerwaniu kutykuli w apikalnej części włoska. Na zalążni kwiatów rurkowatych obserwowano charakterystyczne żebra, które okrywała epiderma zbudowana $\mathrm{z}$ palisadowych komórek wydłużonych w kierunku promieniowym. 
Gruczoły nektarnikowe występowały tylko w kwiatach rurkowatych. Pierścieniowaty nektarnik (93 x $163 \mu \mathrm{m}$; wysokość x średnica) usytuowany był powyżej dolnej zalążni. Strukturę gruczołu tworzyła jednowarstwowa epiderma oraz 5-8 warstw wyspecjalizowanej parenchymy nektaronośnej. Nektar wydzielany był za pośrednictwem zmodyfikowanych aparatów szparkowych o szerokości 15-20 $\mu \mathrm{m}$. Aparaty szparkowe były lekko wyniesione ponad powierzchnię pozostałych komórek epidermy lub znajdowały się nieco poniżej tych komórek. Komórki aparatów szparkowych charakteryzowały się niewielkimi zewnętrznymi i wewnętrznymi listwami kutykularnymi. Na obszarze nektarnika nie obserwowano wiązek waskularnych. Gruczoł odżywiany był przez odgałęzienia wiązek przewodzących biegnących do szyjki słupka, które kończyły się u podstawy nektarnika. Parenchymę nektarnika tworzyły izodiametryczne komórki o średnicy 11-20 $\mu \mathrm{m}$. Wnętrze tych komórek wypełniała elektronowo gęsta cytoplazma zawierająca duże jądro komórkowe, liczne pleomorficzne plastydy, mitochondria z wyraźnym systemem grzebieni, aparaty Golgiego, profile ER oraz rybosomy. Stroma plastydów cechowała się obecnością plastoglobul, intraplastydowych tubul oraz jaśniejszych stref. W każdej komórce występowało kilka niewielkich wakuol. W ścianach niektórych komórek obecne były plazmodesmy. Pomiędzy plazmolemą a ścianą komórkową obserwowano jaśniejszą przestrzeń peryplazmatyczą, w której mógł się odbywać apoplastyczny transport nektaru. Obecność osmofilnej substancji w przestrzeniach międzykomórkowych dodatkowo potwierdza to przypuszczenie. 